\title{
PENGARUH ZAT ALELOPATI DARI ALANG-ALANG TERHADAP PERTUMBUHAN SEMAI TIGA SPESIES AKASIA
}

\section{(THE EFFECT OF ALLOLEPATHY FROM BLADY GRASS TO THREE SPECIES OF ACACIA SEEDLINGS GROWTH)}

\author{
Melda Yanti, Indriyanto, dan Duryat \\ Jurusan Kehutanan, Fakultas Pertanian, Universitas Lampung \\ J1. Soemantri Brojonegoro No. 1 Bandar Lampung, 35145 \\ E-mail : meldayanti17@gmail.com
}

\begin{abstract}
ABSTRAK
Senyawa alelopati merupakan senyawa kimia yang dilepaskan tumbuhan (seperti: alangalang) ke lingkungan tempat tumbuh dan dapat menghambat atau mematikan tumbuhan lainnya. Penelitian bertujuan mengetahui pengaruh zat alelopati dari alang-alang terhadap pertumbuhan semai spesies akasia, mengetahui jenis semai yang terpengaruh paling lemah, serta mengetahui interaksi antara konsentrasi ekstrak alang-alang dengan jenis pohon fase semai. Rancangan percobaan yang digunakan adalah Rancangan Acak Lengkap (RAL) dengan pola faktorial. Faktor I yaitu jenis semai yang terdiri atas akasia, mangium, dan akasia putih, sedangkan faktor II yaitu konsentrasi ekstrak alelopati alang-alang yang terdiri atas tanpa pemberian ekstrak alelopati, pemberian ekstrak alelopati $25 \%$, pemberian ekstrak alelopati $50 \%$, pemberian ekstrak alelopati $75 \%$, dan pemberian ekstrak alelopati $100 \%$. Setiap perlakuan diulang 5 kali. Jumlah semai pada setiap satuan percobaan adalah 2 semai. Variabel yang diamati adalah tinggi, diameter batang, jumlah daun, dan persentase hidup semai. Data diuji menggunakan uji Bartlett untuk mengetahui homogenitas ragam. Kemudian dianalisis dengan analisis ragam, lalu diuji lanjut dengan uji beda nyata terkecil. Taraf nyata yang digunakan dalam semua pengujian adalah 5\%. Hasil penelitian menunjukkan bahwa zat alelopati alang-alang berpengaruh terhadap pertumbuhan semai akasia, mangium, dan akasia putih. Berdasarkan uji BNT pada taraf nyata 5\% diketahui bahwa konsentrasi alelopati alang-alang yang berpengaruh negatif paling kuat terhadap pertumbuhan semai adalah konsentrasi $100 \%$. Jenis pohon fase semai yang paling tahan terhadap alelopati dari alang-alang adalah semai mangium. Dari uji analisis ragam diketahui terdapat interaksi antara jenis pohon fase semai dengan konsentrasi zat alelopati alang-alang yang memengaruhi pertumbuhan tinggi, jumlah daun, dan persentase hidup semai.
\end{abstract}

Kata kunci: alelopati, alang-alang, dan akasia

\section{ABSTRACT}

Allelopathy is the compound released by the plants (example: blady grass) to the environtment and where another plants is living and could obstruct or extinguish to another plants. The purpose of research were to figure out the effect of allelopathy from the blady grass toward the species of acacia seedlings, to figure out the weakest affected seedling species by blady grass allelopathy, and to figure out interaction between concentration of extracted blady grass and seedling tree species. The research was designed based on factorial in a complete random design. Factor I was the seedlings, consisted of acacia, mangium, and acacia alba, while factor II was concentration of extracted blady grass allelopathy, consisted of non extracted allelopathy, extracted allelopathy 25\%, extracted allelopathy 50\%, extracted allelopathy 75\%, and extracted allelopathy 100\%. Every 
treatment was repeated 5 times. The number of the seedlings for each experimental unit was two seeding. The observed variables were height, diameter of the stem, number of leaves, and living percentage of the seedlings. This observation data was tested by Bartlett test to find the variance homogenity. Then it was analyzed by using variance analysis, and tested by least significant difference (LSD). The calculation were done at 5\% significant level. The result of this research showed that allelopathy of blady grass were significan to the growth of acacia, mangium and acacia alba seedlings. Based on the LSD at 5\% was known that the concentrate of blady grass allelopathy had strongest negative effect to the growth seedlings was $100 \%$. Seedling that was the most resistant to the allelopathy of blady grass is mangium seedling. It was known from the analysis of variance test there was an interaction between the seedling and the concentration of blady grass allelopathy that effect the height, leaves number, living percentage ofseedlings.

Key words : allelopathy, blady grass, and acacia

\section{PENDAHULUAN}

\section{Latar Belakang}

Alang-alang (Imperata cylindrica) adalah jenis tanaman pionir yang menyukai sinar matahari dengan bagian yang mudah terbakar di atas tanah dan akar rimpang yang menyebar luas di bawah permukaan tanah. Alang-alang memiliki ketahanan yang tinggi, sehingga tanaman lain harus bersaing dalam memperoleh air, unsur hara, dan cahaya matahari. Jenis tanaman tersebut memberikan pengaruh negatif terhadap pertumbuhan dan perkembangan tanaman lain di sekitarnya, hal ini dikarenakan alang-alang merupakan tumbuhan pengganggu yang mampu melepaskan senyawa alelopati.

Alelopati merupakan senyawa kimia yang terdapat pada tubuh tumbuhan (jaringan tumbuhan) yang dikeluarkan ke lingkungannya dan dapat menghambat atau mematikan individu tumbuhan lainnya (Odum, 1971 terjemahan Samingan, 1993). Pertumbuhan alangalang sangat cepat, menyebar secara luas dan mampu tumbuh pada berbagai kondisi tanah. Sehingga alang-alang banyak tumbuh pada lahan kritis.

Lahan kritis merupakan sebidang lahan yang penggunaan atau pemanfaatannya tidak sesuai dengan kemampuannya. Oleh sebab itu lahan kritis tidak dapat dimanfaatkan secara optimal karena mengalami proses kerusakan fisik, kimia, maupun biologi yang pada akhirnya akan membahayakan fungsi hidrologis, orologis, produksi lahan, pemukiman dan kehidupan sosial ekonomi masyarakat (Djunaedi, 1997). Lahan kritis juga disebut sebagai lahan marginal yaitu lahan yang memiliki beberapa faktor pembatas. Faktor pembatas adalah faktor lingkungan, misalnya unsur hara, air, suhu, kelembapan dan sebagainya yang ketersediaannya dalam jumlah sangat kurang atau berlebihan. Ciri utama lahan kritis adalah gundul, gersang, produktivitas rendah, dan umumnya lahan kritis didominasi vegetasi alangalang. Oleh karena itu salah satu cara mengatasinya adalah dengan menanam jenis tanaman lain yang tumbuh lebih cepat (fast growing).

Akasia (Acacia auriculiformis), mangium (Acacia mangium), dan akasia putih (Acacia alba) merupakan spesies pohon anggota famili Mimosaceae yang memiliki sifat cepat tumbuh (fast growing), sistem perakaran yang padat, dan mampu beradaptasi pada berbagai kondisi tempat tumbuh, sehingga cocok digunakan untuk rehabilitasi lahan kritis yang ditumbuhi alang-alang. Sedangkan alang-alang menghasilkan zat alelopati yang diduga akan memengaruhi pertumbuhan pohon akasia, mangium, dan akasia putih yang ditanam di sekitarnya. Sehingga diperlukan penelitian untuk mengetahui pengaruh zat allelopathy yang dikeluarkan alang-alang terhadap pertumbuhan akasia, mangium, dan akasia putih. 


\section{Tujuan Penelitian}

Tujuan penelitian ini adalah sebagai berikut.

1. Mengetahui pengaruh zat alelopati dari alang-alang terhadap pertumbuhan semai tiga jenis pohon yaitu akasia (Acacia auriculiformis), mangium (Acacia mangium), dan akasia putih (Acacia alba).

2. Mengetahui jenis semai yang terpengaruh paling lemah oleh ekstrak zat alelopati dari alang-alang.

3. Mengetahui interaksi antara konsentrasi ekstrak zat alelopati dari alang-alang dengan jenis pohon terhadap pertumbuhan pohon fase semai.

\section{Manfaat Penelitian}

Manfaat penelitian ini adalah untuk dijadikan referensi dalam pemilihan jenis pohon hutan yang tidak terpengaruh zat allelopathy dari alang-alang, sehingga sesuai untuk pembangunan hutan tanaman di lahan yang beralang-alang.

\section{Kerangka Pemikiran}

Organisme hidup di alam tidak sendiri-sendiri, melainkan menjadi satu kumpulan individu yang menempati suatu tempat tertentu sehingga menghasilkan suatu interaksi antar individu. Amensalisme adalah suatu interaksi negatif antara dua atau lebih spesies yang mengakibatkan salah satu spesies yang berinteraksi terpengaruh negatif dan yang lain tidak terpengaruh. Amensalisme terjadi karena senyawa alelopati yang dilepaskan tumbuhan ke lingkungan tempat tumbuh, sehingga berpengaruh negatif terhadap individu tumbuhan yang sama jenisnya maupun yang berlainan jenis. Salah satu jenis tumbuhan yang mengeluarkan senyawa allelopathy dan menjadi pesaing bagi tumbuhan lain akibat pertumbuhannya yang cepat adalah alang-alang.

Pengaruh senyawa allelopathy yang dikeluarkan oleh alang-alang terhadap tumbuhan fase semai dapat diketahui melalui perlakuan pemberian zat allelopathy dari alang-alang kepada semai akasia (Acacia auriculiformis), mangium (Acacia mangium), dan akasia putih (Acacia alba). Berdasarkan perlakuan tersebut diperoleh respon dari ketiga jenis semai tersebut terhadap pemberian zat alelopati alang-alang, meliputi tinggi semai, diameter batang semai, jumlah daun, dan persentasi hidup semai.

Pengaruh zat alelopati terhadap tumbuhan dapat terjadi melalui proses pembelahan sel, pengambilan mineral, respirasi, penutupan stomata, sintesis protein, dan lain-lain. Jenis bahan kimia yang terkandung pada alelopati pada umumnya berasal dari golongan fenolat, terpenoid, dan alkaloid yang bersifat toksis atau penghambat karena menghasilkan substansi alelokemik yang merugikan tanaman lain (Bima, 2010). Oleh karena itu, diperlukan penelitian untuk mengetahui pengaruh zat alelopati dari alang-alang terhadap pertumbuhan semai akasia, mangium, dan akasia putih.

\section{Hipotesis}

1. Zat alelopati dari alang-alang berpengaruh terhadap pertumbuhan semai tiga jenis pohon yaitu akasia, mangium, dan akasia putih.

2. Semai akasia terpengaruh paling lemah oleh ekstrak zat alelopati dari alang-alang.

3. Terdapat interaksi antara konsentrasi ekstrak zat alelopati alang-alang dengan jenis pohon terhadap pertumbuhan pohon fase semai. 


\title{
METODE PENELITIAN
}

\section{Lokasi dan Waktu Penelitian}

Penelitian dilaksanakan di rumah kaca Fakultas Pertanian Universitas Lampung. Waktu penelitian yaitu bulan Januari hingga Juli 2015.

\begin{abstract}
Alat dan Bahan
Alat yang digunakan adalah jangka sorong (vernier calliper) ketelitian hingga $0,1 \mathrm{~mm}$, neraca analitik ketelitian 0,0001 gram, penggaris ukuran $30 \mathrm{~cm}$ dengan ketelitian 0,00333 $\mathrm{mm}$, kertas label, kamera digital Canon 16,0 megapixel 5x optical zoom, gunting kecil ukuran $10 \mathrm{~cm}$, mortal inersia, gelas piala, batang pengaduk lingkar, kertas saring, corong buchener, labu ukur $100 \mathrm{ml}$ dan mesin Rotary Evaporator. Sedangkan bahan yang digunakan adalah semai akasia (Acacia auriculiformis), mangium (Acacia mangium), dan akasia putih (Acacia alba), alang-alang sebagai sumber zat alelopati, aquades, serta $\mathrm{CH}_{3} \mathrm{CH}_{2} \mathrm{OH}$ (etanol) $96 \%$.
\end{abstract}

\section{Metode Penelitian}

Rancangan percobaan yang digunakan dalam penelitian adalah Rancangan Acak Lengkap (RAL) dengan pola faktorial (3x5). Faktor I adalah jenis semai (A) yang terdiri atas akasia $\left(\mathrm{A}_{1}\right)$, mangium $\left(\mathrm{A}_{2}\right)$, dan akasia putih $\left(\mathrm{A}_{3}\right)$. Faktor II adalah konsentrasi ekstrak alelopati alang-alang (B) yang terdiri atas kontrol atau tanpa pemberian ekstrak alelopati alang-alang $\left(\mathrm{B}_{0}\right)$, pemberian ekstrak alelopati alang-alang $25 \%\left(\mathrm{~B}_{1}\right)$, pemberian ekstrak alelopati alang-alang 50\% (B $\left.\mathrm{B}_{2}\right)$, pemberian ekstrak alelopati alang-alang $75 \%\left(\mathrm{~B}_{3}\right)$, dan pemberian ekstrak alelopati alang-alang $100 \%\left(\mathrm{~B}_{4}\right)$. Setiap perlakuan diulang 5 kali. Jumlah semai pada setiap satuan percobaan adalah 2 semai. Dengan demikian kombinasi yang dicobakan sebanyak 3 × 5 x $5=75$ unit.

Pelaksanaan penelitian ini dilakukan dengan tahapan kegiatan sebagai berikut.

1. Penyemaian benih akasia, mangium, dan akasia putih

Benih akasia, mangium, dan akasia putih diambil dari pohon induk di Arboretum, kemudian diseleksi berdasarkan keseragaman ukuran benih sebelum dikecambahkan. Sebelum dikecambahkan, benih-benih tersebut diberi perlakuan skarifikasi untuk mematahkan dormansi pada benih. Kemudian benih disemai pada bak kecambah yang berbahan plastik dengan ukuran $40 \mathrm{~cm}$ x $30 \mathrm{~cm}$ menggunakan media semai berupa pasir.

2. Penyapihan semai akasia, mangium, dan akasia putih

Penyapihan dilakukan dengan cara semai akasia, mangium, dan akasia putih dipindahkan ke dalam polibag dengan media tanah. Penyapihan semai dilakukan saat semai berumur 2 bulan.

3. Ekstraksi Zat Alelopati

Ekstraksi zat alelopati dari alang-alang dilakukan dengan tahapan sebagai berikut.

a. Pengambilan alang-alang dari daun hingga akar tanaman untuk diekstraksi. Alangalang diambil dengan cara mencabut dari tanah menggunakan tangan ataupun sekop, lalu ditimbang berat awalnya dan disimpan di kantong plastik.

b. Penjemuran alang-alang di bawah sinar matahari selama 1-2 hari (tergantung kondisi cuaca). Kemudian dipotong kecil - kecil dan dihaluskan lalu disimpan pada wadah yang aman.

c. Ekstraksi zat alelopati alang-alang dengan Metode Maserasi. Alang-alang yang telah dihaluskan ditaruh di wadah kemudian diberi pelarut etanol $\mathrm{CH}_{3} \mathrm{CH}_{2} \mathrm{OH} 96 \%$ sebanyak 5 1, diaduk dan ditutup rapat selama 24 jam.

d. Penyaringan bahan alang-alang untuk diekstraksi menggunakan mesin Rotary Evaporator. 
e. Pengaturan suhu dan tekanan pada tombol mesin Rotary Evaporator untuk mendapatkan hasil ekstrak yang maksimal. Kemudian dilakukan pengenceran dengan konsentrasi yang diinginkan.

4. Pemberian perlakuan zat alelopati

Zat alelopati yang dihasilkan dari ekstrak alang-alang diberikan pada semai akasia, mangium, dan akasia putih yang telah disapih ke dalam polibag. Pemberian zat alelopati dilakukan setiap satu minggu selama 2 bulan dengan dosis zat alelopati yang berbeda, yaitu $0 \%, 25 \%, 50 \%, 75 \%$, dan $100 \%$.

Pengamatan

Variabel yang diamati dalam percobaan ini adalah sebagai berikut.

1. Tinggi semai

Tinggi semai diukur mulai dari kolet sampai dengan buku-buku batang teratas. Pengukuran dilakukan pada awal dan akhir penelitian.

2. Diameter batang semai

Diameter batang semai diukur menggunakan kaliper dan dilakukan pada awal dan akhir penelitian.

3. Jumlah daun

Jumlah daun dihitung dengan cara menghitung seluruh jumlah daun yang hidup pada semai. Pengukuran dilakukan pada awal dan akhir penelitian.

4. Persentase hidup semai

Persentase hidup semai dihitung dengan rumus sebagai berikut.

Persentase hidup $=\frac{\sum \text { semai yang tumbuh }}{\sum \text { seluruh semai }} \times 100 \%$

5. Berat kering total semai

Berat kering total dihitung dengan cara menimbang sampel semai yang telah dioven hingga bobot konstan. Pengukuran dilakukan pada akhir penelitian.

Analisis Data

Data dianalisis menggunakan uji Barlett untuk mengetahui homogenitas ragam kemudian dilanjutkan dengan analisis sidik ragam. Untuk mengetahui pengaruh zat alelopati alang-alang yang paling lemah terhadap pertumbuhan semai akasia, mangium dan akasia putih dilakukan uji perbandingan dengan Uji Beda Nyata Terkecil (BNT).

\section{HASIL DAN PEMBAHASAN}

\section{Hasil}

Seluruh variabel penelitian diuji dengan uji Bartlett untuk mengetahui homogenitas ragam. Setelah didapatkan data yang homogen, maka dilakukan analisis ragam untuk mengetahui adanya perlakuan yang memberi pengaruh nyata terhadap pertumbuhan semai akasia, mangium,dan akasia putih. Hasil rekapitulasi analisis ragam seluruh variabel pertumbuhan semai akasia, mangium, dan akasia putih disajikan pada Tabel 1. Hasil analisis ragam menunjukkan bahwa terdapat paling tidak satu perlakuan atau kombinasi perlakuan yang berpengaruh nyata terhadap setiap variabel pertumbuhan semai akasia, mangium, dan akasia putih. Oleh karena itu untuk mengetahui perlakuan atau kombinasi perlakuan yang memberikan pengaruh nyata, maka dilakukan uji BNT. Hasil uji BNT pengaruh perlakuan terhadap pertumbuhan semai akasia, mangium, dan akasia putih disajikan dalam Tabel 2 dan Tabel 3 sebagai berikut. 
Tabel 1. Rekapitulasi analisis ragam untuk seluruh variabel penelitian pengaruh zat alelopati dari alang-alang terhadap pertumbuhan semai akasia, mangium, dan akasia putih.

\begin{tabular}{|c|c|c|c|c|c|c|}
\hline \multirow[b]{2}{*}{ Perlakuan } & \multicolumn{4}{|c|}{$\mathrm{F}_{\text {hitung }}$ pada setiap variabel penelitian } & \multirow[b]{2}{*}{$\begin{array}{c}\text { Berat } \\
\text { kering total }\end{array}$} & \multirow[b]{2}{*}{$\mathrm{F}_{0,05}$} \\
\hline & $\begin{array}{c}\text { Persentase } \\
\text { pertambahan } \\
\text { tinggi semai }\end{array}$ & $\begin{array}{c}\text { Persentase } \\
\text { pertambahan } \\
\text { diameter }\end{array}$ & $\begin{array}{l}\text { Persentase } \\
\text { pertambahan } \\
\text { jumlah daun }\end{array}$ & $\begin{array}{l}\text { Persentase } \\
\text { hidup semai }\end{array}$ & & \\
\hline $\begin{array}{l}\text { Jenis semai } \\
\text { (A) }\end{array}$ & $73,99 *$ & $8,71 *$ & 0,64 tn & 2,00 tn & $42,57 *$ & 3,15 \\
\hline $\begin{array}{l}\text { Konsentrasi } \\
\text { alelopati } \\
\text { alang-alang } \\
\text { (B) }\end{array}$ & $8,78^{*}$ & $1,28 \mathrm{tn}$ & $352,86 *$ & $20,89 *$ & $1,85 \mathrm{tn}$ & 2,53 \\
\hline $\mathrm{AxB}$ & $4,14 *$ & $1,53 \mathrm{tn}$ & $8,23 *$ & $2,56^{*}$ & $1,62 \mathrm{tn}$ & 2,10 \\
\hline
\end{tabular}

Tabel 2. Rekapitulasi hasil uji BNT pengaruh jenis semai terhadap persentase pertambahan tinggi, diameter batang, dan berat kering total semai akasia, mangium, dan akasia putih.

\begin{tabular}{lccc}
\hline $\begin{array}{c}\text { Pengaruh utama } \\
\text { jenis semai }\end{array}$ & $\begin{array}{c}\text { Persentase } \\
\text { pertambahan tinggi } \\
(\%)\end{array}$ & $\begin{array}{c}\text { Persentase } \\
\text { pertambahan diameter } \\
(\%)\end{array}$ & $\begin{array}{c}\text { Berat kering total } \\
(\mathrm{g})\end{array}$ \\
\hline Akasia & $21,59 \mathrm{~b}$ & $15,73 \mathrm{bc}$ & $0,85 \mathrm{ab}$ \\
Mangium & $12,01 \mathrm{a}$ & $9,78 \mathrm{a}$ & $1,92 \mathrm{c}$ \\
Akasia putih & $24,25 \mathrm{c}$ & $14,74 \mathrm{~b}$ & $0,79 \mathrm{a}$ \\
\hline $\mathrm{BNT}_{0,05}$ & 2,12 & 3,06 & 0,28 \\
\hline
\end{tabular}

Keterangan:

Data pada setiap kolom yang diikuti oleh huruf yang sama tidak berbeda pada taraf nyata $5 \%$.

Berdasarkan hasil uji BNT diketahui bahwa jenis semai akasia, mangium, dan akasia putih berpengaruh nyata terhadap persentase pertambahan tinggi. Semai mangium berpengaruh nyata terhadap persentase pertambahan diemeter. Namun berat kering semai mangium terpengaruh paling lemah dibandingkan dengan semai akasia dan akasia putih.

Tabel 3. Rekapitulasi hasil uji BNT pengaruh konsentrasi alelopati alang-alang terhadap persentase pertambahan tinggi, jumlah daun, dan persentase hidup semai akasia, mangium, dan akasia putih.

\begin{tabular}{lccc}
\hline $\begin{array}{c}\text { Pengaruh utama } \\
\text { konsentrasi alelopati } \\
\text { alang-alang }\end{array}$ & $\begin{array}{c}\text { Persentase } \\
\text { pertambahan tinggi } \\
(\%)\end{array}$ & $\begin{array}{c}\text { Persentase } \\
\text { pertambahan daun } \\
(\%)\end{array}$ & $\begin{array}{c}\text { Persentase } \\
\text { hidup semai } \\
(\%)\end{array}$ \\
\hline Tanpa alelopati & $23,15 \mathrm{de}$ & $30,23 \mathrm{e}$ & $100,00 \mathrm{~b}$ \\
Konsentrasi 25\% & $20,53 \mathrm{~cd}$ & $-42,75 \mathrm{~d}$ & $100,00 \mathrm{~b}$ \\
Konsentrasi 50\% & $19,70 \mathrm{bc}$ & $-56,24 \mathrm{c}$ & $100,00 \mathrm{~b}$ \\
Konsentrasi 75\% & $17,19 \mathrm{ab}$ & $-76,99 \mathrm{~b}$ & $86,67 \mathrm{~b}$ \\
Konsentrasi 100\% & $15,86 \mathrm{a}$ & $-95,78 \mathrm{a}$ & $33,33 \mathrm{a}$ \\
\hline BNT $_{0,05}$ & 2,73 & 7,28 & 17,8 \\
\hline
\end{tabular}

Keterangan:

Data pada setiap kolom yang diikuti oleh huruf yang sama tidak berbeda pada taraf nyata $5 \%$. 
Berdasarkan hasil uji BNT diketahui bahwa pemberian alelopati alang-alang dengan konsentrasi yang berbeda tidak berbeda nyata terhadap persentase pertambahan tinggi semai. Namun konsentrasi alelopati alang-alang berbeda nyata terhadap persentase pertambahan jumlah daun dan persentase hidup semai, yaitu semakin tinggi konsentrasi alelopati yang diberikan maka semakin rendah persentase pertambahan jumlah daun dan persentase hidup semai.

Hasil analisis ragam menunjukkan bahwa terdapat interaksi antara jenis semai dengan konsentrasi zat alelopati alang-alang yang memengaruhi pertumbuhan semai akasia, mangium, dan akasia putih. Dengan demikian untuk mengetahui interaksi yang memberikan pengaruh nyata terhadap pertumbuhan semai dilakukan analisis ragam lanjutan. Hasil analisis ragam lanjutan pengaruh interaksi terhadap pertumbuhan semai disajikan dalam Tabel 4 sebagai berikut.

Tabel 4. Rekapitulasi analisis ragam lanjutan pengaruh interaksi jenis semai dengan konsentrasi alelopati alang-alang.

\begin{tabular}{|c|c|c|c|c|}
\hline \multirow[b]{2}{*}{$\begin{array}{l}\text { Perbandingan } \\
\text { perlakuan }\end{array}$} & \multicolumn{3}{|c|}{$\mathrm{F}_{\text {hitung }}$ pada setiap variabel penelitian } & \multirow[b]{2}{*}{$\mathrm{F}_{0,05}$} \\
\hline & $\begin{array}{l}\text { Persentase } \\
\text { pertambahan } \\
\text { tinggi semai }\end{array}$ & $\begin{array}{l}\text { Persentase } \\
\text { pertambahan } \\
\text { jumlah daun }\end{array}$ & $\begin{array}{l}\text { Persentase } \\
\text { hidup } \\
\text { semai }\end{array}$ & \\
\hline $\begin{array}{l}\text { Antara kontrol } \\
\text { (tanpa alelopati) } \\
\text { dengan alelopati }\end{array}$ & $60,02 *$ & $35,00^{*}$ & $24,00 *$ & 10,13 \\
\hline $\begin{array}{l}\text { Antara jenis } \\
\text { pada kontrol }\end{array}$ & $5,9 *$ & $0,0003 \mathrm{tn}$ & $8,33 *$ & 3,15 \\
\hline $\begin{array}{l}\text { Antara jenis } \\
\text { pada konsentrasi } \\
\text { alelopati } 25 \%\end{array}$ & 0,002 tn & $10,82^{*}$ & $8,33 *$ & 3,15 \\
\hline $\begin{array}{l}\text { Antara jenis } \\
\text { pada konsentrasi } \\
\text { alelopati } 50 \% \\
\end{array}$ & $6,02 *$ & $1,24 \operatorname{tn}$ & $8,33^{*}$ & 3,15 \\
\hline $\begin{array}{l}\text { Antara jenis } \\
\text { pada konsentrasi } \\
\text { alelopati } 75 \% \\
\end{array}$ & $2,84 \mathrm{tn}$ & $40,1 *$ & $3,00 \mathrm{tn}$ & 3,15 \\
\hline $\begin{array}{l}\text { Antara jenis pada } \\
\text { konsentrasi alelopati } \\
100 \%\end{array}$ & $5,22 *$ & $38,4 *$ & $8,33 *$ & 3,15 \\
\hline $\begin{array}{l}\text { Antara konsentrasi } \\
\text { alelopati pada semai } \\
\text { akasia }\end{array}$ & $114,56 *$ & $22,09 *$ & $80,28^{*}$ & 2,53 \\
\hline $\begin{array}{l}\text { Antara konsentrasi } \\
\text { alelopati pada semai } \\
\text { mangium }\end{array}$ & $53,3 *$ & $26,08^{*}$ & $71,11 *$ & 2,53 \\
\hline $\begin{array}{l}\text { Antara konsentrasi } \\
\text { alelopati pada semai } \\
\text { akasia putih }\end{array}$ & $199,06 *$ & $15,42^{*}$ & $111,11 *$ & 2,53 \\
\hline
\end{tabular}

Berdasarkan hasil analisis ragam interaksi jenis semai dengan konsentrasi alelopati alang-alang diketahui bahwa terdapat paling tidak satu kombinasi perlakuan antara jenis semai pada kontrol atau tanpa pemberian zat alelopati alang-alang yang berpengaruh terhadap persentase pertambahan tinggi dan persentase hidup semai, namun tidak berpengaruh terhadap persentase jumlah daun. Interaksi yang berpengaruh negatif paling kuat terhadap 
pertumbuhan semai adalah interaksi antara jenis semai pada pemberian alelopati alang-alang dengan konsentrasi $100 \%$. Interaksi antara konsentrasi alelopati alang-alang dengan semai mangium berpengaruh paling kuat terhadap pertambahan jumlah daun, sedangkan interaksi antara konsentrasi alelopati alang-alang dengan semai akasia putih berpengaruh paling kuat terhadap pertambahan tinggi dan persentasi hidup semai.

\section{Pembahasan}

\section{Jenis semai}

Jenis semai berpengaruh terhadap pesentase pertambahan tinggi, diameter, dan berat kering total semai. Hasil uji BNT menunjukkan bahwa jenis semai akasia, mangium, dan akasia putih berpengaruh terhadap persentase pertambahan tinggi semai. Hal ini karena semai akasia, mangium, dan akasia putih memiliki sifat tumbuh yang cukup cepat (fast growing) dan mampu tumbuh pada berbagai kondisi tempat tumbuh. Sesuai dengan Attamimi (2003) yang menyatakan bahwa pohon famili mimosaceae seperti akasia memiliki kecepatan tumbuh yang cepat dan tidak akan terhambat pertumbuhannya jika tidak ada senyawa penghambat di sekitar lingkungan tempat tumbuhnya. Naning (2013) juga mengemukakan bahwa mangium lebih mampu bertahan dan beradaptasi pada lingkungan tempat tumbuhnya dibandingkan dengan jenis lainnya.

Semai mangium berpengaruh paling lemah terhadap berat kering dibandingkan dengan semai akasia dan akasia putih. Hal ini diduga semai mangium mampu mentolerir zat alelopati yang dikeluarkan alang-alang dan di lapangan anakan mangium dapat hidup berdampingan dengan alang-alang. Mangium dapat bertahan meskipun terdapat alangalang di sekitarnya karena mangium merupakan jenis yang toleran terhadap pengaruh senyawa kimia. Senyawa kimia yang dilepaskan alang-alang tidak memengaruhi aktivitas hormon untuk melakukan pembelahan dan perbesaran sel. Sesuai dengan Krisnawati, dkk (2011) bahwa pohon akasia mampu berkompetisi dengan gulma yang agresif, seperti alang-alang dan mampu mengatur nitrogen udara, sehingga digunakan untuk merehabilitasi sifat-sifat fisika dan kimia tanah.

Mangium memiliki zat penyusun kayu yang lebih baik dibandingkan dengan bagian pohon lainnya. Zat penyusun kayu tersebut diduga menyebabkan bagian rongga sel pada batang banyak tersusun oleh komponen penyusun kayu dibandingkan dengan air, sehingga bobot batang akan menjadi lebih besar. Sesuai dengan Hania (2011) yang menyatakan bahwa batang mangium memiliki biomassa yang lebih besar dibandingkan jenis pohon famili Mimosaceae lainnya karena tersusun atas zat penyusun kayu yang menyebabkan struktur menjadi padat.

Akar mangium berfungsi sebagai pemasok air, mineral dan bahan-bahan yang penting untuk pertumbuhan dan perkembangan tanaman. Pertumbuhan akar pada mangium diduga dapat meningkatkan jumlah pasokan bahan-bahan yang berperan dalam proses fotosintesis yang pada akhirnya dapat meningkatkan pertumbuhan dan perkembangan tanaman. Rata-rata berat kering tanaman terbesar dihasilkan oleh semai mangium, karena semai mangium mampu mengikat nitrogen lebih besar dibandingkan spesies lainnya. Ryan (2014) menyatakan bahwa berat kering akan bertambah dengan semakin bertambahnya kandungan nitrogen dan phospor dalam tanah.

2. Zat alelopati alang-alang

Pemberian zat alelopati alang-alang berpengaruh terhadap persentase pertambahan tinggi, jumlah daun, dan persentase hidup semai akasia, mangium, dan akasia putih. Hal ini karena alang-alang mampu melepaskan senyawa alelopati yang bersifat alelokemis dari tubuhnya dan dapat menghambat atau mematikan tumbuhan lain di sekitarnya. Senyawa 
alelokemis yang dikeluarkan alang-alang ke lingkungan tempat tubuhnya diduga memberikan efek yang mampu mencegah tanaman bertunas dan tanaman baru tumbuh. Hal ini sesuai dengan Indriyanto (2008), bahwa alelopati merupakan pengaruh yang merugikan atau menghambat secara langsung maupun tidak langsung dari suatu tumbuhan terhadap tumbuhan lain melalui produksi senyawa kimia yang dilepaskan dan dibebaskan ke lingkungan hidup tumbuhan.

Alang-alang (Imperata cylindrica) merupakan jenis tumbuhan yang mengandung senyawa kimia seperti gugusan asam organik, gula, asam amino, pektat, asam giberelat, terpenoid, alkaloid, dan fenolat. Senyawa fenolat merupakan senyawa yang larut dalam air. Senyawa fenolat yang terlarut dapat berpengaruh pada proses pertumbuhan tanaman, bergantung kepada konsentrasinya. Salisbury dan Ross (1995) menyatakan bahwa jika konsentrasi fenolat dalam air tinggi, maka potensial lingkungan akan naik sehingga menghambat difusi air dan oksigen ke dalam suatu tanaman. Jika suplai air ke dalam tanaman terhambat, maka proses pembelahan dan perbesaran sel juga akan terhambat.

Pertumbuhan semai yang sangat terganggu adalah semai dengan pemberian alelopati 100\%. Hal ini ditunjukan dengan semai yang mengalami gangguan fisiologis pada tubuhnya sehingga proses pertumbuhan semai terhambat bahkan mengalami kematian pada semai diduga akibat senyawa kimia beracun yang terdapat pada semai sangat tinggi sehingga semai tidak mampu mentolerir senyawa kimia tersebut. Pengaruh alelokimia tehadap pertumbuhan semai terjadi melalui serangkaian proses, yaitu diawali dengan pecahnya membran plasma atau hilangnya fungsi enzim. Sehingga berpengaruh terhadap penyerapan dan konsentrasi ion dan air yang kemudian memengaruhi dan menghambat proses fisiologis tumbuhan, seperti fotosintesis, sintesis protein, dan pembukaan stomata. Hal ini sesuai dengan Rijal (2009) bahwa bahan kimia yang bersifat racun akan mengganggu proses pembelahan dan perbesaran sel yang akhirnya menghambat pertumbuhan dan perkembangan tumbuhan.

3. Interaksi antara jenis semai dengan konsentrasi ekstrak alelopati alang-alang.

Analisis ragam tentang pengaruh interaksi antara jenis semai dengan konsentrasi alelopati alang-alang berpengaruh nyata terhadap pertumbuhan semai akasia, mangium, dan akasia putih. Interaksi antara jenis semai pada kontrol atau tanpa pemberian ekstrak alelopati berpengaruh terhadap persentase pertambahan tinggi dan persentase hidup semai, namun tidak memengaruhi pertambahan jumlah daun. Hal ini menunjukkan bahwa jenis yang berbeda-beda tidak memengaruhi pertambahan jumlah daun jika tanpa pemberian zat alelopati dikarenakan tidak terdapat senyawa kimia yang bersifat penghambat dan aleloemis pada lingkungan tempat tumbuh. Sehingga semai akan tetap menghasilkan tunas baru. Hal ini sesuai dengan Windarti dkk. (2004) bahwa jika tanaman tumbuh pada lingkungan yang tidak terdapat senyawa penghambat maka hormon pada jaringan tumbuhan tidak akan mengalami gangguan, namun jika terdapat senyawa penghambat maka hormon pada jaringan akan berubah.

Interaksi antara jenis semai pada konsentrasi alelopati alang-alang berpengaruh terhadap persentase pertambahan tinggi, jumlah daun dan persentase hidup semai. Hal ini menunjukkan bahwa jenis yang berbeda-beda memengaruhi pertumbuhan semai jika terdapat konsentrasi alelopati yang diberikan terhadap semai. Alelopati alang-alang mengandung senyawa kimia yang mampu menghambat dan mematikan semai bergantung kepada konsentrasi. Semakin tinggi konsentrasi alelopati alang-alang yang diberikan pada semai, maka persentase pertumbuhan semai semakin rendah. Hal ini diduga senyawa alelokemis atau senyawa racun yang terdapat pada alang-alang mampu menyebabkan gangguan keseimbangan hormon pada tumbuhan. Perubahan hormon tersebut menyebabkan proses fisiologis pada tumbuhan seperti fotosintesis akan terganggu. 
Proses fotosintesis merupakan proses fisiologis tumbuhan yang menghasilkan senyawa penting untuk pertumbuhan suatu tanaman seperti penambahan jumlah daun yang membutuhkan karbohidrat, protein, lemak, bahan-bahan organik lainnya. Semai yang mengandung senyawa kimia bersifat toksin akan menghambat sistem kerja hormon dalam proses fotosintesis. Perubahan kerja pada hormon mengakibatkan laju fotosintesis rendah, maka semai tidak mampu memproduksi energi berupa ATP dan NADPH. Sehingga semai tidak mamu menghasilkan zat makanan dan bahan organik lainnya untuk pertumbuhan. Hal ini sesuai dengan pernyataan Windarti dkk. (2004) bahwa keracunan sekitar tempat tumbuh menyebabkan perubahan keseimbangan homon. Perubahan hormon menyebabkan terganggunya aktivitas fotosintesis, sehingga pertumbuhan semai akan terhambat. Salisbury dan Ross (1995) juga menyatakan bahwa sitokinin sebagai salah satu fitohormon yang dipengaruhi racun akan menghambat kemampuan daun untuk kuncup dan bertunas.

\section{KESIMPULAN}

Adapun kesimpulan yang diperoleh dari penelitian ini yaitu sebagai berikut.

1. Zat alelopati dari alang-alang berpengaruh terhadap pertumbuhan semai akasia, mangium, dan akasia putih. Konsentrasi zat alelopati dari alang-alang yang berpengaruh negatif paling kuat terhadap pertumbuhan semai adalah konsentrasi $100 \%$.

2. Jenis semai yang paling tahan terhadap zat alelopati alang-alang adalah semai mangium. Zat alelopati alang-alang berpengaruh paling lemah pada berat kering total semai mangium dibandingkan dengan semai akasia dan akasia putih.

3. Interaksi antara jenis semai dengan konsentrasi zat alelopati dari alang-alang berpengaruh terhadap pertumbuhan semai akasia, mangium, dan akasia putih. Interaksi yang berpengaruh negatif paling kuat terhadap pertumbuhan semai adalah interaksi antara jenis semai akasia putih pada konsentrasi alelopati alang-alang 100\%.

\section{DAFTAR PUSTAKA}

Alfiatus. 2013. Pengaruh allelopati daun alang-alang (Imperata cylindrica) terhadap perkecambahan biji terong (Solanum melongena). Skripsi. Universitas Negeri Surabaya. Surabaya. 66 p.

Bima. 2010. Alelopati. Buku. Universitas Negeri Surabaya. Surabaya. 174 p.

Djunaedi, D. 1997 Kriteria Kesesuaian Lahan untuk Komoditas Pertanian. Buku. Pusat Penelitian Tanah dan Agroklimat. Badan Penelitian dan Pengembangan Pertanian. Bogor. $21 \mathrm{p}$.

Gaspersz, V. 1994. Metode Rancangan Percobaan untuk Ilmu-ilmu Pertanian, Teknik dan Biologi. Buku. CV Armico. Bandung. 472 p.

Indriyanto. 2008. Ekologi Hutan. Buku. Penerbit Bumi Aksara. 210 p.

Krisnawati, H., M. Kallio, M. Kanninen. 2011. Acacia Mangium Willd. Ekologi, Silvikultur, dan Produktivitas. Buku. CIFOR. Bogor. 26 p.

Naning, Y. 2013. Pengaruh metode ekstraksi dan ukuran benih terhadap mutu fisik fisiologis benih akasia. Jurnal Penelitian Hutan Tanaman. 10 (3). 129-137 p.

Odum, E. P. 1971. Fundamentals of Ecology. Buku. (Terjemahan Tjahjono Samingan. 1993. Ed. B. Srigandono. Dasar-dasar Ekologi). Gadjah Mada University Press. Yogyakarta. $697 \mathrm{p}$.

Purwitasari, Hania. 2011. Biomassa pohon akasia mangium (Acacia mangium). Jurnal Penelitian. 26 (4). 50-66 p.

Rijal, N. 2009. Mekanisme dan penerapan serta peranan alelopati dalam bidang pertanian. Jurnal Penelitian. 40 (1). 80 p. 
Ryan, A. K. 2014. Pengaruh alang-alang terhadap pertumbuhan semai Gmelina arborea. Jurnal Penelitian. 35 (1). 31-42 p.

Sastrosupadi. 2000. Rancangan Percobaan Praktis untuk Bidang Pertanian. Buku. Penerbit Kanisius. Yogyakarta. 30 p.

Salasbury, F.B. dan Ross. 1995. Fisiologi Tumbuhan. Buku. ITB Press. Bandung. 212 p.

Windarti. 2004. Pertumbuhan dan akumulasi tanaman pada cekaman selama masa pembibitan. Jurnal Ilmiah Lingkungan Hidup. 4 (2). 68 p. 
Vol. 4 No. 2, April 2016 (27-38)

Halaman ini sengaja dikosongkan 